\title{
The Zapatistas and the art of ventriloquism
}

\author{
PEDRO PITARGH
}

At the end of 1993, a revolutionary organization called the Zapatista Army of National Liberation (Ejercito Nacional de Liberación Nacional - EZLN) was making its final preparations to take power in Mexico by armed force. It appeared to be an absurd undertaking. On the one hand, this army, which had been operating in a clandestine fashion in a corner of the state of Chiapas, made up of a relatively small number of poorly armed indigenous peasants, was going to declare war on the Mexican government and army. But the enterprise also seemed uncertain in political terms. At that time, the EZLN defined itself according to the conventional terminology of an armed, left-wing, revolutionary organization: a front line group, leading the working class, with the idea of taking power and installing a socialist political regime. At a time when such revolutionary attempts had been widely discredited, and after the peace accords between governments and guerillas in Central America, its language and ideology seemed somewhat out of place.

And yet, a short time after the armed uprising had taken place on January 1st, 1994, the Zapatista army managed to substantially alter its profile and present itself to public opinion as an ethnic movement, a defender of indigenous culture and its traditional order. In other words, within the space of a few months, the EZLN had moved from defending the Revolution to defending 'identity politics'; its cause was no longer socialism but Indian dignity. This new way in which the Zapatistas presented themselves inverted the initially weak situation and not only managed to save the organization, but provoked an extraordinary resonance and public response. But identity politics has its limitations. By shedding its revolutionary language and adopting an ethnic rhetoric, the Zapatistas also committed themselves to a type of politics that turns out to be difficult to abandon once it has been chosen.

\section{First changes}

The EZLN's internal documents and propaganda immediately before 1994 leave no doubts about its Marxist orthodoxy. In 1993, the Forces of National liberation (Fuerzas de Liberación Nacional-FLN) - the immediate forerunner to the EZLN - defined their task in the following terms: 'The objectives of the Party are to organize, lead and to place itself at the head of the revolutionary struggle of the working classes in order to take power away from the bourgeoisie, free our country from foreign domination and install a proletarian dictatorship, understood as a government of workers that prevent a counter-revolution and begin to build socialism in Mexico' (Declaration of Principles of the Forces of National Liberation Party, in De la Grange and Rico 1998: 226). For their part, the EZLN's 'Insurrectionary Rule' - the oath that every person had to take on joining the organization - says, for example: 'I swear before the memory of the heroes and martyrs of our people and the international proletariat

$$
\text { Journal of Human Rights }
$$

ISSN 1475-4835 print/ISSN 1475-4843 online @ 2004 Taylor \& Francis Ltd

http://www.tandf.co.uk/journals

DOI: $10.1080 / 1475483042000224851$ 
that I will defend the revolutionary principles of Marxist - Leninism and their application to national reality... I swear that I will fight, to the death if necessary, the enemies of my motherland and for socialism. To live for the motherland or to die for freedom' (De la Grange and Rico 1998: 228).

Therefore, there was nothing in the declared aims or in the language of the EZLN that distinguished it from other Latin American groups of Marxist persuasion that had attempted to reproduce the Cuban revolution through an armed struggle. But the EZLN's way of presenting itself was to suffer an upset with the start of the war. On the night of December 31 and January 1, some 3000 guerillas left their camps in Las Cañadas region of the jungle and militarily took control of various towns and cities in the center of Chiapas. That same day, the EZLN made public its 'Declaration of the Lacandón Forest', which had been written a few months earlier. Directed at the Mexican people, the tone of the document is considerably different from the internal bulletins and propaganda that had defined the EZLN until a few weeks previously. With this document, there begins what might be termed the Zapatistas' 'popular-nationalist' phase. A passage says:

But we TODAY SAY ENOUGH! we are the inheritors of those who really forged our nationality, we, the dispossessed, are millions and we call upon all our brothers to join this plea as the only way not to die of hunger before the insatiable ambition of a dictatorship that has lasted more than 70 years, led by a coterie of traitors that represent the most conservative and least patriotic groups. They are the same people who opposed Hidalgo and Morelos, those that betrayed Vicente Guerrero and the same as those who sold more than half our soil to a foreign invader, they are the same as those who formed the dictatorship of porfirian scientists, the same who opposed the Nationalization of our oil industry, the same as those who massacred the railway workers in 1958 and the students in 1968, the same people who take everything away from us today, absolutely everything. (EZLN, 1994a)

One of the most conspicuous aspects of the Declaration of the Lacandón Jungle is the complete disappearance of leftist, revolutionary language. Instead, it has been replaced by the nationalist rhetoric of the Mexican Revolution, a far more conventional idiom with which Mexicans are very familiar. The key to the argument presented in the Declaration lies in the presentation of the Zapatista army as a movement with both a national and epic character, struggling against foreigners or, to be more precise, against a Mexican government that has sold itself to foreigners; in other words, an illegitimate government. An appeal of this nature is, of course, universal, but there is perhaps something characteristically Mexican in the tight association made between the EZLN and national heroes - in their fight against betrayal and usurped legitimacy - that explains the fantastic reverberation that the Declaration had. In fact, the Mexican constitution itself was invoked in the text, reminding people that national sovereignty lay with the people, and that they 'have, all the time, the inalienable right to alter or modify the shape of their government'. Therefore, instead of using the predictable language of the revolutionary left, which would undoubtedly have alienated broad sectors of the Mexican population, the EZLN used the same discourse that successive PRI governments had employed during the last seven decades in order to confer legitimacy upon themselves. The Declaration of January 1st ended with the demand for 'work, land, housing, food, health, education, independence, liberty, democracy, justice and peace'.

The Marxist-Leninist language was strategically put to one side, but the Indianist language had yet to make its appearance. Little has been made of the fact - so noticeable in retrospect - that the words 'indigenous' and 'Indian' hardly appear in the first communiqués; 
not even as a social group that could be put on the same level as the 'workers, peasants, students, honest professionals, Chicanos and progressives from other countries', to whom the Declaration was directed. Despite the fact that the best part of the Zapatista army was made up of indigenous people from Chiapas, the language used by the leaders was still far from being an identity discourse. The 'Indians' or 'indigenous persons' still did not exist as a discreet category, probably being subsumed within the category of 'peasants' ('campesinos'), a common practice amongst leftist revolutionaries for whom 'Indian' was still a 'culturalist' category that was associated more with anthropological mystification than with an objective and materialist analysis of reality. Furthermore, amongst the numerous Revolutionary Laws that would be applied to those areas liberated by the Zapatista army - the War Tax Law, the Law of Rights and Obligations of Peoples in Resistance, the Law of Rights and Obligations of Revolutionary Armed Forces, the Revolutionary Agrarian Law, the Women's Revolutionary Law, the Urban Reform Law, and others - there was no Indigenous Rights Law.

Let us return for a moment to the events of the beginning of January 1994. Once the towns of central Chiapas had been occupied, the Zapatistas, in accordance with their 'prolonged popular war' plan, should have advanced to Mexico City. Perhaps they hoped that their exploits would act as a spark that would set the whole country alight. But it did not happen like that. The reaction of the Mexican army was immediate and forceful, as they already knew about the existence of the EZLN, and a few days later the Zapatistas retreated to Las Cañadas region from which they had emerged. At that moment, they could have been wiped out. Luckily, however, a good number of journalists and Mexican and international observers descended upon Chiapas almost by magic, and the pressure of national and international public opinion, perhaps along with the regime's negotiating tradition, obliged the Mexican government to adopt a non-military solution. On January 12th, the Mexican president, Carlos Salinas de Gortari, declared a ceasefire and announced an amnesty law and the initiation of negotiations.

\section{Indians in the media}

The fact is that the EZLN did not have anything specific to negotiate. For years it had been preparing itself to take power and political negotiations did not fit with its plans. Subcomandante Marcos himself admitted as much in an interview not long afterwards: 'it jumped so quickly from the military phase to the political phase that we were not ready for dialogue' (Chiapas 1994: 164).

At that moment and in those circumstances, the press began to play a key role. Of course, the Mexican and international media fell over each other to report on events in Chiapas, but there was one newspaper in particular, La fornada, that not only reported the news, but intervened decisively in the rapid reconstruction of the EZLN's public image. On the one hand, La fornada was the newspaper that gave the greatest coverage to Chiapas, a level of attention that was almost exclusive during the first few months. But, above all, because of the open sympathy that it showed for the Zapatistas and its admiration for their leader, this newspaper became the principal means by which subcomandante Marcos broadcast his communiqués and propaganda. [De la Grange and Rico (1998) - two reporters that have covered the conflict in Chiapas - describe the 'starry-eyed' attitude of the press before this character. The reporters gave themselves over to him without doubting the information that he was providing them. In the press conferences, which were meticulously prepared and full of dramatic effects, he is applauded and those who ask awkward questions are jeered at by the 
rest. Marcos vetoes those journalists that do not report on the EZLN in a sympathetic manner and journalists promote self-censorship 'in order not to play into the government's hands'.]

From the first days of the conflict, La fornada referred to members of the EZLN as 'Indians' or 'indigenous peasants' and to the armed rebellion as an Indian movement. The first reference, as far as I know, that Marcos made to 'indigenous people' was on January 2nd, 1994 in the press conference he gave in the main square of San Cristóbal de Las Casas. In a long interview with reporters from La fornada, the following phrase slipped out: the North American Free Trade Agreement represents a 'death sentence for the indigenous ethnic groups of Mexico'. That was the only allusion he made to the indigenous question in the whole interview, but the subheading of the article written by the journalist was: 'It is an ethnic movement' (Perez and Rojas 1994).

Initially, the term 'Indian' was used with weak connotations. The Indians were basically poor and illiterate peasants, and what made them so was their economic marginalization. Therefore, in the first few days, both the news and editorial articles insisted on these conditions of illiteracy, housing without drainage and electricity, with dirt floors, and on other circumstances in which the indigenous people of Chiapas found themselves. It was also insisted - although with very little information ${ }^{1}$ - that estate owners and cattle ranchers had monopolized all the land and that there had been no genuine agrarian reform in the state: 'A class that has nothing to lose and everything to win with a revolution'; 'The Mexican Revolution never really arrived in Chiapas'. In many senses, they were still the 'Indians' that readers could immediately associate with the army of Emiliano Zapata, that is, Nahuatlspeaking peasants, but apart from that detail, they were not very different from any other poor Mexican peasant. The commonly used expressions brought together the two words: 'indigenous-peasant people', 'the indigenous-peasant uprising'.

Furthermore, the opinion columns during those first few months characterized the movement as agrarian: 'The problem in Chiapas is land. The dispute for land is at the heart of the Chiapanecan conflict' or 'The Chiapas conflict is primarily agrarian, and only afterwards racial, social and political'. The identification of the rebels with the legendary figure of Zapata seemed to enjoy a certain currency in the first few months of 1994 (after all, the insurgents defined themselves as Zapatistas), and in fact images of Zapata and indigenous persons would be closely associated for some time. The EZLN's first communiqués made continual reference to Zapata and on April 10th, the EZLN lavishly celebrated the anniversary of his birth in their base camps, an event widely reported by the press. Subcomandante Marcos even began to speak about the indigenous belief in Votán-Zapata in his communiqués, a sort of fusion between a supposed Maya deity - Votán - and the Mexican hero Votán is a figure that was alluded to by a 17 th century Spanish bishop, but is completely unknown to contemporary indigenous people in Chiapas. Nonetheless, many believed in it and maintained that it represented an essential Maya belief, like the balaclavas and other inadvertent emblems of the Zapatistas). But, importantly, this identification with Zapata did not, in the end, fare well with public opinion and ended up being diluted and then abandoned, as much by the press as by the Zapatistas themselves.

In contrast, the identification of the movement with 'indigeneity' was to have extraordinary success, although the actual meaning of 'indigenous' would change with the passing of the months. Its use gradually lost its negative connotations of a population characterized by its marginality and deficiencies and acquired more positive associations, primarily based on ideas of identity. Instead of simply being Indians, little by little they became 'ethnic groups' ('étnias'), and later on, 'indigenous peoples' ('pueblos indígenas'), groups with their own, distinctive culture. They were not just people distinct from the majority of Mexicans, they were also more authentic and morally superior. 
Editorial articles in the press participated in this gradual change of perception in significant ways. Throughout 1994 and even in 1995, numerous Mexican intellectuals felt the need to write an article in La fornada explaining - and explaining to themselves - the causes of the Chiapas rebellion. (But this was not limited to Mexican intellectuals: the conflict in Chiapas also - especially in southern European countries - generated a reassessment of the role of the intellectual, which was rediscovering what appeared to be a clearly defined moral cause without the ambiguities that had cast a shadow over views regarding other conflicts, such as Iraq and the Yugoslavian wars.) Except for the first few months, when economic marginalization and the land issue were the most common explanations, the opinion of the articles centered around the value of indigenous cultures and their relevance for Mexican identity. For example, a relatively early article stated:

Faced with intolerance, Chiapas pushes to the forefront the Indian struggle to recover their dignity, and this does not just mean defeating misery and marginalization, but also respecting their beliefs, their customs and their particular visions of mankind and the universe. They represent repositories of knowledge of the ancient Mexicans. How much of this knowledge remains amongst contemporary Mesoamerican indigenous communities? We cannot even answer this question. What characteristics does the fusion of ancient knowledge and western wisdom have? Whatever this may be, our country has changed, it has to change, and Chiapas is Mexico. We cannot carry on humiliating ourselves. (Flores 1994)

The line of thinking in this paragraph is very representative. Such opinions stress the standard stereotypes regarding indigenous people - their wisdom, their relationship with nature, respect for others, direct democracy, etc. - but what is more is that indigenous peoples reflected, like a mirror, 'the true face of Mexico', a face that modernity, or attempts at modernity, served to obscure. As for other articles, a large number were written by Mexican anthropologists for whom, like the majority of anthropologists in the world, the question of identity had become the academic issue of the moment. This process was also accompanied by a flood of art exhibitions and scientific meetings concerning Mexican indigenous cultures.

The interesting thing is that the editorial articles concerned themselves with indigenous peoples in general and not with the Zapatista Army of National Liberation. Although the general and rather abstract portrayal of the former did not explain the armed uprising of the latter, they appeared to be practically the same thing. Within a few months, they managed to produce a direct correlation between the EZLN and indigenous people, despite the fact that the EZLN represented a minority of Indians in Chiapas. Later, this correlation would be made with all of Mexico's indigenous people. Thus, to be on the EZLN's side was to be on the Indians' side and, perhaps more importantly, to be on the Indians' side meant supporting the Zapatistas. The formidable density and diversity of both religious and political organizations to which the indigenous people of Chiapas belong (such as trade union organizations, agrarian organizations, different types of Catholics, evangelical Protestants, national political parties, civil associations, 'Indianist' movements, etc.) was suddenly eradicated from the stage to leave only two leading players: the Mexican government and the EZLN, the latter having turned into the representative of the million or so indigenous people in Chiapas. The Mexican government itself seemed prepared to accept this equivalence, perhaps because of its ignorance of the Chiapanecan reality (a fact that should not be ignored, especially at the beginning of the conflict), or perhaps because on seeing the conflict as an indigenous problem, it reduced the nationwide and radical character of the Zapatistas' initial demands. 
The distance between, on the one hand, the reality of the Zapatista army as a local armed organization and, on the other, its new international public image became incommensurable in a strict sense because they could not really be compared. In local terms, the EZLN was - and continues to be up to the present day, possibly even more so now - a hierarchical and authoritarian organization, as one would expect of an army disposed to take power: a group that uses a good dose of coercion to combat not only internal differences - its political and military personnel are systematically purged by the leadership - but also in its dealings with alternative indigenous organizations. According to information from the International Red Cross, during 1994, between 25,000 and 30,000 indigenous people had to leave Las Cañadas region (populated by around 100,000 people), for political reasons, or rather, because of confrontations with the EZLN. In other words, at an internal level, the Zapatista army behaved much like any other 20th century Latin American revolutionary guerilla group.

In contrast, the EZLN managed to present itself publicly - and this is perhaps its novelty - as a non-authoritarian, egalitarian group, based on forms of indigenous democracy ('The discourse of the EZLN - wrote a priest - refers to a new element in the term democracy, where the community decides the course of action and chooses who will carry it out'; Lampe 1996: 84), tolerant of political difference, conciliatory, without pretensions of taking power, etc.

Furthermore, once inextricably linked to the Indians, the EZLN disposed of its history as an armed organization and settled into a sort of fabulous limbo period. The image that cast the Zapatistas as a movement that had suddenly emerged out of nowhere became commonplace in innumerable articles and books: 'The rebellion that came out of the night', 'Those that emerged from the depths of the jungle', 'Those that materialized out of dark times'. The few attempts to trace the internal history of the Zapatistas, including those works predisposed to their cause, were strongly denied by sympathizer circles. So attractive was the absence of a history of the Zapatistas and of an identity for subcomandante Marcos that the government's crude attempt in February 1995 to combat his popularity by revealing his true identity (Rafael Guillén from Tampico, a professor at the Metropolitan Autonomous University, with an UNAM philosophy degree) and, juxtaposing his photograph with and without balaclava, ended up having the opposite effect. A few days later there was a crowded demonstration in Mexico City where the protesters chanted: 'All of us are Marcos!'

So, how can we explain the fact that the media, and particularly the press, had such a prominent role in the recreation of the Zapatista movement? It is possible that the answer to this has something to do with the weakness of the public sphere in Mexico, where political actors ideally have access to public opinion and where issues can be discussed openly. In circumstances where wide sectors of the Mexican population lack a public voice, it is the intellectuals and the press that are in charge of interpreting 'the nation's feelings' (Lomnitz 1999). It seems to me that this has been particularly the case in the Chiapas conflict. In indigenous communities, movements and organizations, there has been practically no way to access national public opinion. Between the former and the latter, there exists a profound communication gap, to which can be added the difficulties of intercultural translation. Something that immediately catches one's attention is the fact - which as far as I know has not been analyzed - that in Mexico in general and in particularly in Chiapas, there hardly exist any indigenous intellectuals. In contrast to other Latin American countries, such as Guatemala or Bolivia, there are no indigenous public figures that might be capable of representing indigenous sectors of the population. It seems significant that in January 1994, the Guatemalan Indian, Rigoberta Menchú, along with Bishop Ruiz and a Mexican journalist, was proposed as a mediator between the EZLN and the government, although 
in the end the nomination of the Nobel Peace Prize winner did not come to anything; as if at that time there was no recognized indigenous public figure with sufficient prestige to be considered in a situation of this nature. But, above all, on the more local level of indigenous communities and organizations, political mediators are incapable of intervening in collective opinion, perhaps precisely because, traditionally at least, political relations have taken place in spaces that have not been very public. Consequently, this void was filled by the media and by Mexican intellectuals, who took charge of defining the needs and opinions of the indigenous population.

This is perhaps one of the most astonishing aspects of the conflict in Chiapas. Despite the nine years that have passed and the thousands of articles and hundreds of books dedicated to the analysis the phenomenon, indigenous voices have hardly been heard at any point. ${ }^{2}$ The fantasy involved in the representation of indigenous 'feelings' and their invention on the part of intellectuals can only be explained by the very ample space that the latter enjoy to carry out such an exercise.

\section{The 'Indian' language of subcomandante Marcos}

So, it was the question of identity, 'indigenous identity', that finally ended up imposing itself on public opinion as the privileged lens through which to view events in Chiapas. With the benefit of hindsight, perhaps such a development was foreseeable given the currents in intellectual opinion at the end of the century, and particularly the surge in the politics of recognition and multiculturalist premises regarding political participation at the expense of the enlightenment principles of development and redistribution (i.e. the roots of injustice are found not in a poor distribution of goods and resources, but in a lack of cultural recognition).

Nevertheless, certain aspects of the process are more circumstantial, amongst them being the role of the Zapatista leader. We have already referred to the role of the press and the intellectuals, but the process cannot be explained solely by their behavior. In a militarily delicate situation, to say the least, the chances that the EZLN would survive obviously depended on being able to maintain a certain resonance with public opinion and to keep up the sympathies that had been stirred during those first few weeks. Subcomandante Marcos made the most of these circumstances. If the press served as a model for what people outside of Chiapas wanted to hear, pointing out which proposals, images and idioms were having an impact and which were not, the Zapatista leader showed great intuition in following and encouraging such demands. In such a way, there emerged a relationship of reciprocal expectations and a mutual dependence between Marcos and 'informed opinion'. In this dialectical game, Marcos tailored his proposals according to demand, and the demand was in turn adjusted according to the EZLN's needs. We have already seen how Marcos, as well as the press, 'tested out' the association of the EZLN with the figure of Zapata, but given that this connection did not appear to capture the imagination of national public opinion (why?), it was virtually abandoned (although abroad this association was undoubtedly more successful).

It is probable that Marcos' willingness to adapt the image of his organization was assisted by the fact that he was militarily surrounded, which meant that communication between Marcos and the rest of the EZLN leadership in other parts of Mexico - clandestine and under threat of persecution - was very difficult. Marcos thus found himself as the effective leader of the Zapatistas and was free to redirect the group's policies and politics. In any case, Marcos must have sensed the opportunity offered by the EZLN to make the most of the fact that the majority of his army, and the communities that supported it, were indigenous. 
A few weeks before the armed uprising took place, the subcomandante had created the Indigenous Revolutionary Clandestine Committee (Comité Clandestino Revolucionario Indígena - CGRI). In contrast to the EZLN Comandancia, whose leaders had military posts and, above all, were not, in their majority, indigenous people, the CCRI was a sort of 'elders' council' ('consejo de ancianos'), without military responsibilities. The Committee was presented to the press as the real leaders of the EZLN, to which the military posts were subordinated (De la Grange and Rico 1998). It is probable that it was presented in such a way to prevent the accusation that the indigenous people were being manipulated for the benefit of an outside political project.

During the next few months, the subcomandante's language underwent a strange transformation. It definitely lost its Marxist vocabulary, but it also abandoned, to a large extent, explicitly urban and politically conventional language. Although it seems that Marcos does not speak an Indian language, he began to speak like the Indians. Or rather, he began to speak in a way that the urban population imagines that Indians speak: a strange mixture of expressions in archaic, Chiapanecan Spanish, the syntax of Indians in Western movies and motifs from the European romantic, pastoral genre. Taking an example from a section of the Second Declaration of the Lacandón Jungle - a text that, given its formal character, is not particularly 'Indian' - published on June 12, 1994:

So spoke the word of the heart of our forever dead. We saw that our dead's word is good, we saw that there is truth and dignity in their counsel. Therefore we call upon all our Mexican indigenous brothers and sisters to resist with us. We call upon all the campesinos to resist with us, upon workers, employees, colonists, housewives, students, teachers, upon those who make thought and word their life, upon all of those who have dignity and shame, we call upon everyone to resist with us, because the bad government does not want democracy on our soil. We will accept nothing that comes from the rotten heart of the bad government, not a single coin nor a medicine nor a stone nor a grain of food nor a crumb from the handouts that it offers in exchange for our dignified path. (EZLN, 1994b)

There are evident differences in style between this text (also obviously written by Marcos) and the First Declaration of the Lacandon Jungle, published only four months beforehand. But also some of the categories have been modified. Now the indigenous people themselves spoke: the 'we' does not correspond to the poor and the dispossessed of Mexico in general, but specifically to the indigenous population, who, for example, address the campesinos as if they were a different category. This 'we' also includes subcomandante Marcos, who used the personal pronouns interchangeably, moving continually from ' $\mathrm{I}$ ' to 'we, the indigenous people' in the same text. There are times when Marcos turns into an 'Indian' and his readers were fascinated; not only did he fulfill the expectations of formulaic images, but in a feedback dynamic, he also contributed to their very creation.

Within a very short time, this pastiche language came to be understood as a true 'Indian' language and was not only subjected to examinations of varying seriousness to discover within it ancient Indian cosmogonies, but it's style began to be imitated by many. It could be heard amongst Mexican pro-Zapatistas, international visitors, journalists, and even began to spread amongst congressmen, senators and government workers. Even the Mexican president, Ernesto Zedillo, began to speak in 'Indian' in his speeches to indigenous people. Marcos' Indian language was so particular and so difficult to imitate that even on the very rare occasions that the Zapatista leaders of indigenous origin did speak in public or were interviewed, their words words ended up being, at least in terms of the 'show', somewhat 
disappointing and not particularly - or sufficiently - 'Indian'. And to complicate matters, their language was also inappropriately out of date as it was permeated by a conventional, Marxist discourse, learnt in the EZLN's schools of political instruction.

We have at our disposal a huge number of interviews with subcomandante Marcos, often published as books by journalists and intellectuals from all over the world. But in hardly any of these do we hear the voices of his indigenous military subordinates, and even less so the voices of grassroots indigenous Zapatistas (many of whom speak Spanish); and, of course, the voices of non-Zapatista indigenous peoples never appear. Paradoxically, for the Mexican and international audience, the words of Marcos not represented only an indigenous language, but, more precisely, represented the only legitimate indigenous language.

\section{The effect of ventriloquism}

This technique may be labeled as 'ventriloquism'; that is, the art of giving one's voice distinct intonations and altering it in such a way that it appears to emanate from a different source. In other words, subcomandante Marcos projected his own interests and political strategies, making them appear, through some simple stylistic tricks and common place themes, as if they came from the indigenous population of Chiapas. What ensured this fiction was that it was not subcomandante Marcos nor the EZLN leadership (professional revolutionaries at the end of the day) that were opposed to, for example, neoliberalism or NAFTA, but something much newer, unpredictable and exotic: the Indians.

This was a key strategy because through this ventriloquism effect the EZLN's political demands acquired enormous weight. Setting oneself up as a spokesperson and a defender of Indians is not like turning oneself into a representative of any other sector of the Mexican population. This identification with the Indian world, or rather, being identified with Indian people by public opinion, affords significant symbolic capital with which to negotiate in the Mexican political arena. As a matter of fact, a multitude of agents - the state, the Catholic Church, evangelical churches, political parties and innumerable political and cultural organizations - have all strived to establish a sort of 'magic contact' with indigenous people that affords their respective causes an extra legitimacy. Indigenous people are thought to be on the margins of society ('In some place in the Lacandon Jungle', as subcomandante Marcos' communiqués tend to begin), and these margins confer power. Nevertheless, it was the EZLN (perhaps along with the Catholic Church) who best and most credibly managed to acquire and administer this magic. ${ }^{3}$

But if we are to be more precise, what was being projected in this ventriloquist discourse was not exactly, as we have seen before, the leftist revolutionary ideas of the EZLN leadership, but the popular-nationalist language that, quite rightly, subcomandante Marcos imagined the Mexican public wanted to hear. Thus we have the Indians of Chiapas - a population that from a historical, geographical and social perspective was totally tangential to the central tradition of Mexican nationalism - appearing to defend the pillars of national principles. It is this unlikely juxtaposition - Indians, literal and metaphorical inhabitants of the jungle, defending national traditions - that gave this association its enormous power. It is not necessary here to go into the role that American Indians people have played as radical 'others' in the Western imagination. Suffice to say that in Mexico in particular, 'Indianness' is deeply linked to how the nation sees itself. It is imagined not only in its past, but also in its essence, an essence that in moments of crisis tends to come to the surface. The editorial articles in the press reveal a sort of nationalist nostalgia, precisely when the country was opening itself up to the international economy; and the indigenous population embodied 
this nostalgia: 'Deep Mexico'. One could write a history of the various Mexican identity crises by following the moments in which the 'Indian question' appears openly in public discourse (through criticisms of state indigenist projects, proposals for new policies and laws, until the issue eventually loses interest and ends up disappearing from the public debate to find shelter yet again in the academic world). Something like this occurred during the months following the Zapatista uprising in 1994. It seemed as if the whole country had lain down on the analyst's couch in the Lacandon jungle. It cannot be said that it was a particularly reflexive or critical phenomenon, but rather a collective catharsis in which politicians, intellectuals and public opinion in general talked about the indigenous people of Chiapas, but only in appearance, because they were actually talking about Mexico, an 'imagined community'.

The target of Marcos' speeches was undoubtedly the Mexican population. But his words, perhaps unintentionally at the beginning, caught the imagination of a much wider audience. The Zapatista rebellion met with support from extraordinarily wide and diverse groups of people and political positions in different countries. It has been said that this is due to the particular character of the Zapatista movement, whatever that might be. But in my view, it seems that this attraction is rather the result of the opposite, namely, its lack of character and absence of a clear identity. It is true that Marcos' texts and interviews incorporate multiple registers with which to reach distinct audiences. But Zapatismo's most characteristic hallmark - particularly with regards to a politically defined program - is its calculated vagueness, its ability to appear to say a lot without really saying anything in particular. The words have a certain value in of themselves and the speeches, which relish every sentence, are drawn out by going over and over simply expressed ideas. A little like the language of exotic 'wise sayings' - with which this 'Indian' language has much in common - everyone can find something they are looking for in it because it is an empty language that means nothing. Consider, for example, the most successful 'Indian' phrases that ended up serving as mottos: 'to rule through obeying', 'for everyone, everything, for us nothing', etc.

The consequence of this vagueness is that almost any political position is able to see itself reflected in Zapatista discourses. This explains why the character of Zapatismo has been interpreted politically in such different ways, according to the perspective of each author. We have, for example, Zapatismo as multiculturalism (mainly by US commentators) and another version where Zapatismo represents a sort of specific universalism (particularly by French authors). There is also a Christian Zapatismo derived from Liberation Theology (with its old testament language of an Indian people chosen by God and protective of its differences) and Zapatismo as interpreted by neo-anarguist movements (with its promise of a world without frontiers). Furthermore, we find Zapatismo cast as a postmodern political movement ('beyond capitalism and socialism') or as an expression of indigenous revival (a movement that brings the primordial Maya soul up to date); and so on. It is always worth citing a paragraph, a text or a sentence that appears to corroborate one's own ideas.

Given that we are dealing with an imprecise language (but also given that many commentators take the speeches as representative of reality and do not concern themselves with what is happening within the Zapatista army nor in the communities that it controls), Zapatismo ends up acting as a mirror that reflects whatever image is projected on to it, be it nationalist, feminist, ecologist ... One commentator beautifully expressed this quality: '.. as the number of rebel communiqués grew, we began to realize that the uprising came from something deep within ourselves' (García de León 1994: 14). Furthermore, what should not be lost sight of is that this dynamic became possible by virtue of the fact that it is the Indians who act as the mirror. It is the fact that the indigenous people appear to be those who speak that makes them legitimate and even turns idioms, proposals, controversies that 
have been exhausted in other parts of the world and in more conventional scenarios into something novel. In the deepest parts of the jungle, the public finds the dream of an Indian that says exactly what the public wants and needs to hear. In such a way, Marcos, through this 'Indian' language, projected not only his own voice, but also managed to project other peoples' voices, our own voices.

This ventriloquist's game worked extraordinarily well for quite a long time, and still does in certain respects. But we have to wonder if it was really believed and to what extent. This is not a simple question to answer because it is not easy to distinguish here between genuine conviction and the desire that all be true. Even the activists that were mobilized by the Zapatista cause appeared to accept the possibility that it was nothing but a dream (some also said a 'myth'), but even so, they were prepared to experience this dream as if it were real; that is, to believe, sometimes in a slightly desperate way, that the Indians were genuinely saying what they appeared to be saying and that the EZLN, after all the disappointment with guerilla movements at the end of the 20th century, was what it said it was: a movement that articulated profound indigenous ideas (i.e. non-Western ones), that were anti-authoritarian, democratic and that did not intend to take power.

It is likely that the majority of the interested Mexican and international public accepted this pretension, with greater or lesser reservations. At the end of the day, from a distance it was difficult to work out whether the Zapatistas really constituted a democratic movement or whether the indigenous people of Chiapas really talk like subcomandante Marcos does in his texts. (Although, to tell the truth, there did not seem to exist much inclination to ask these kinds of questions.) In practice, what occurred was a curious inversion in how the ventriloquist's game was interpreted, through which Marcos simply acted as the spokesperson for the Indians. Instead of Marcos speaking through the Indians, it was the Indians who spoke through him. In an article that appeared in the newspaper El Pais, some Spanish apologists explained this function in the following way: 'Given that the majority [of the Indians] do not speak Spanish and their languages are Maya in origin and have a very distinct structure to our language, they needed somebody that spoke Spanish well so that their story might be known, and they chose the person called subcomandante Marcos' (Colectivo Solidaridad Ya 1998). This is an idea that the Zapatista leader often insisted upon. The fact that the main protagonist of a movement that identified itself as indigenous was not indigenous carried on producing considerable discomfort. Throughout 1994, the Zapatista army staged a number of public acts where the Indians entrusted Marcos with their representation. For example, in a literal exercise of ventriloquism, Marcos writes a text in which a ceremonial staff is handed over by an indigenous person who is made to give a speech in which Marcos is named leader and spokesperson for indigenous people:

In this land goes the home of the greatest of our dead. We are the same dead as always, those who have to die forever. We are the dead that live. This is the death that gives life to all our brothers. Always remember that our struggle is for life. Seven forces: Tzotzil, Tzeltal, Tojolabal, Chol, Mame, Zoque and Mestizo. May the struggle grow by seven times seven. Seven words and seven paths: life, truth, man, peace, democracy, freedom and justice. Seven paths that give strength to the ceremonial staff of the leader of true men and women. Receive, then, the ceremonial staff of the seven forces. Carry it with honor and may the words that true men and women do not utter never inhabit it. You are no longer you, now and for always you are us. (EZLN, 1995a: 140) ${ }^{4}$

At the other extreme, Marcos' sudden 'Indianness' caused much amusement amongst small groups of radical left-wing militants, but they had to acknowledge that the Zapatista 
leader's new role represented a master stroke of political strategy. Even the Popular Revolutionary Army (Ejército Popular Revolucionario - EPR), the guerrilla organization that reappeared in 1996 and is known for its Marxist orthodoxy, presented a manifesto in both Spanish and Nahuatl.

However, the position adopted by a complex group of apologists for Zapatismo was somewhat more interesting and subtle. These people, who lived in Chiapas or who had a good knowledge of the indigenous world due to having worked there for a long time, included a good number of anthropologists from Mexico and particularly from the US and Europe. It seems to me that in this case one cannot really talk of naivete. They were able to recognize the sham, or at least some of its more conspicuous aspects. They knew, for example, that Votán-Zapata was not an indigenous hero, but an ad hoc invention that had propaganda intent. But they pretended that it was all real and legitimate, as if the Indians were those that were really speaking in the Zapatista army's manifestos and documents. This attitude can most probably be explained by the fact that the deplorable economic and political situation of the indigenous population, with the PRI in power after so many decades, did not appear to have a ready solution apart from an armed uprising. To side with the EZLN was, as we have seen, to side with the Indians. (However, in this regard, I believe that this group allowed itself to be seduced too easily by the epic and aesthetic character of these indigenous revolutionaries, and very soon a democratic exit to the problem was rejected.)

But there was more to it than just this. A situation akin to that of 'the emperor's new clothes' was produced within this group. Everyone seemed to be involved in keeping up the illusion, everyone imagining that it was other people who believed in it, whilst, in reality, nobody completely believed in the illusion that was being produced. It was if everyone was scared that someone - oneself for example - would point out that it might all be a farce, or at least point to some of the more evident contradictions (the emperor is naked!) and consequently the illusion would suddenly crumble. It was not unlike a reciprocal game of pretences similar to certain rituals that have been described in the South American lowlands, where, as Crocker explains regarding a Bororo ceremony, 'people act as if something they know to be false were true, so true that certain grave dangers await those do not act falsely' (1983: 170). Nobody believed in it, but everyone had to pretend they believed because if they did not, a very real catastrophe might occur.

In any case, I am sure that subcomandante Marcos had not renounced his conventional revolutionary Marxist ideology - despite his public and ironic distancing from it. In his speeches - not so much in his communiqués - it is not difficult to notice the oblique and knowing signs and gestures that were directed at extreme left-wing Mexican activists: a nod to the Cuban revolution (whose date only has meaning to the 'initiated'), a reference to the fall of the Berlin wall, etc. In October 1994, Marcos wrote a letter of reply to the Mexican historian Adolfo Gilly, who had suggested to him that his language (that is, the language of the Indians in Marcos' texts) appeared to follow what the Italian historian Carlo Ginzburg, in a celebrated article about micro-history ('Clues: roots of an evidential paradigm') had called 'evidential' or 'conjectural' logic. But here Marcos, yet again 'between us left-wing intellectuals' (despite it being a public letter), adopted a distinct tone to the usual one. Marcos considered Ginzburg's posture of avoiding a dichotomy between 'rationalism' and 'irrationalism' to be just another variation of an idealist position: 'In reality, the problem in the sciences occurs in the struggle between materialism and idealism (Ah, Lenin is now censured! Ah, the forgotten Materialism and Empirocriticism! [Lenin's text]. Ah, Mach and Avenarius revived! Ah, the stubbornness of Vladimir Ilyich!' (Subcomandante Marcos 1995a: 105). Historical materialism, the science of history founded by Marx, was developed as a critique of idealism and 'class position' had been deemed as the basis of an objective knowledge of 
history. In sum, seven or eight months after having adopted apparently ethnicist positions, along with this 'Indian' language, Marcos openly and almost aggressively maintained here a principle of abstract and Marxist universalism. But he kept it up for himself and for those that already agreed with him.

\section{The imaginary Indian}

Generally speaking, indigenous cultures show very little concern for questions of collective identity (an issue which, to be truthful, is a characteristically European obsession). In fact, Indians from Chiapas - especially the more conservative ones - have no difficulty in rapidly and consecutively modifying the ways in which they identify and present themselves. This is evident, for example, in the incessant changes in religious affiliations, when indigenous people 'convert' a number of times to different churches in the space of a few years; but the same happens with electoral choices, political affiliations, ideological views, etc. Loyalty (be it religious, political, ideological) is, in the best of cases, a transitory exercise.

Nonetheless, the change in the way that the Zapatista army was presented was so sudden that it took even its indigenous members by surprise. The declarations of the indigenous guerillas to the press revealed their partial ignorance of the direction their leadership had taken. Captain Roberto: 'we don't want any more changes in government, because this war is for socialism ... here it's socialism that will have success'; Captain Arturo: 'Socialism is the only way to finish with this system, where there are rich people who eat peacefully sat at their table, whilst the campesinos are breaking their backs and don't have anything'; and another young man later commented: 'When we have socialism . . . or rather when we achieve the acceptance of the 10 points ...' (Redondo 2002: 26-27).

Within a short period, the indigenous people who made up the Zapatista base communities and filled their ranks found themselves in a paradoxical situation. For years they had tried to break with part of their traditional practices - especially the women - after being politically indoctrinated with the idea of class struggle, but now they had to show themselves to be essential Indians. The majority of these indigenous people belonged to communities from the region known as Las Cañadas, which is in between the sierra and the jungle, whose inhabitants come from the old estates and migrant groups from traditional communities in the Highlands. These colonists began to enter the jungle from the 1950s onwards, cultivating the land with very little help from government institutions, which consequently had little control over these new communities. Many of the colonists were young and, on escaping the authority of the elders in their communities of origin, partially cast off their old cultural practices. Meanwhile, the Catholic Church found a warm welcome in this region and managed to promote a militant religious and political project under the inspiration of bishop Samuel Ruiz. ${ }^{5}$ The migration and settlement in the jungle were reinterpreted with reference to the biblical Exodus: the Chosen People in their flight from Egypt (Leyva 1995). The missionary project insisted on the acceptance of indigenous culture as part of this new society that was being created in the jungle, but what the missionaries understood by indigenous culture was a version virtually purged of traditional practices and was closer to a universal interpretation of a primitive Christian community. Similar to what occurred in Guatemala a decade before (the comparison with the Guatemalan case is revealing), the activities of the diocese and other religious orders prepared the ground for revolutionary groups from Mexican urban areas who installed themselves in the region, often invited by the diocese itself in their as technicians, such as agronomists. The ideology promoted by the Church turned into the 'translator' between the indigenous population and the urban 
revolutionaries, and the catechist networks became the connecting point between the clandestine structures of the revolutionary organization. The indigenous catechists were the main way in which the EZLN recruited its members, and the EZLN, in turn, turned into a sort of guarantor for a new public morality, severely sanctioning, for example, drunkenness and adultery.

Given all this, it remains ironic that, in the new situation created by the uprising, the Zapatistas had to resort to cultivating an ethnographic disguise. Ethnic markers began to appear - ceremonial staffs, traditional dress for the authorities, fragments of public ritual that were more appropriate to the traditional sectors of those communities with which they found themselves confronting ideologically.

It is clear that this 'ethnic' display was largely based on a fiction, whose purpose was to conceal not only the Zapatistas, but also the Tzotzil, Tzeltal and Tojolobal indigenous groups in general. In fact, it did not need the indigenous population, which did not really participate in this deployment of the 'ethnic' factor, but rather an unreal indigenous figure. Using Baudrillard's expression, the Indian served as a 'simulacrum', that is, an operation that provides all the signs pertaining to the real, but without the appearance of any of its contradictions and fluctuations (Ramos 1994). The cultural diversity represented by the indigenous population offered the chance to promote more open and plural relations in the country as a whole. But the use of this indigenous fiction actually worked in the opposite way because the real indigenous population, with all its diversity and contradictions, inevitably ended up as an easily manipulable and suffocating abstraction. For example, there was a tendency to reify indigenous communities as isolated entities, thus exaggerating their internal bonds and often ignoring the ways in which they depended on the state. Their level of internal homogeneity was also exaggerated, to the extent that it sometimes legitimated the repression of internal differences in the name of the community and new forms of rule by assembly. On occasions, it became so shrouded in mystery that indigenous culture became beyond reproach.

Thus, as in other moments in the past, there was a process by which the negative indigenous stereotype was simply inverted, and the pressure of this resulting image was such that indigenous people themselves had no alternative but to fulfill this fictitious role if they wanted to be heard. Public discussion regarding the problems experienced by the Indian population became almost impossible, and questions concerning democratic representation and political legitimacy were consigned to the background, largely for the benefit of the spectacle.

\section{'Indigenous rights'}

Thus in a year and a half, from the end of 1993 to the middle of 1995, the EZLN had covered the following sequence: Marxist-Leninist > popular-nationalist $>$ Indianist. But up until that moment, the Zapatistas' Indianism remained extremely vague, more akin to a moral position than a political program. It was still a stance that emphasized the lack of government assistance and the Mexican state's age-old disregard for the indigenous population. In fact, the (relative) detailing of such a political program did not come from the EZLN leadership but from a small group that acted as advisers to the Zapatistas during their negotiations with the government.

In October 1995, negotiations began in the village of San Andrés Larráinzar, the outcome of which would be known as the San Andrés Accords. In line with the initial plan, four panels were to be held: (1) indigenous rights and culture, (2) democracy and justice, 
(3) welfare and development, and (4) women's rights. The Zapatistas had a large group of advisers that, before commencing the negotiations, visited the EZLN leadership to receive instructions. One of them remembered subcomandante Marcos' response: 'The political watchword is that there isn't one'. And he continued:

The EZLN wanted the advisers and guest delegates to contribute to the definition of the main currents in the Zapatista positions regarding the initial panel (Indigenous rights and culture), on the basis of their distinct experiences and perspectives. With specific reference to the issue of autonomy, Marcos stated that the Zapatistas had their own experiences, but that they had not managed to put together a finished proposal based on these; in any case, they had not intended to take their own proposal to the panel. Rather, they hoped that their advisers and guest delegates would work on the different suggestions and approaches in search of a common proposal. 'What you agree upon regarding autonomy is what the EZLN will take on and defend' the sub concluded, more or less in those words. (Díaz-Polanco 1997: 188)

Made up of people largely from academia, some of them anthropologists, it was this group of advisers that worked on and gave sense to the name of the panel, 'Indigenous rights and culture'. It was these advisers that furnished a more articulate discourse on the politics of indigenous identity, particularly with regard to the notion of ethnic autonomy, that is, the creation autonomous regions, governed in accordance with 'practices and customs' ('usos $y$ costumbres') or 'local normative systems' ${ }^{6}$ In this way, through the San Andrés discussions, a group of academics managed to introduce into the national debate some proposals that they had been working on for years, but that until that moment were marginal, even in university circles. At the same time, through these proposals, the Zapatistas' various political positions began to acquire more coherence and become more specific. In fact, the concept of ethnic autonomy came to be in practice one of the most visible and explicit elements in their political demands. At that moment, the Zapatistas set themselves the goal of creating 'autonomous municipalities' and 'autonomous regions', although there were undoubtedly tactical reasons for doing so. To reiterate, it was the proposals concerning 'indigenous rights and culture', that is, proposals regarding identity issues, that ended up acquiring greater relevance at the expense of the other initial questions (democracy and justice, welfare and development and women's rights).

Some time would still pass before the Zapatistas scaled down, if not theoretically, at least in practice, their more general political demands. But the adoption of a defense in terms of 'indigenous rights' essentially fixed the EZLN's new direction and political profile. Some time later, subcomandante Marcos would state it clearly: 'The basis of our struggle is the demand regarding indigenous rights and culture, for that is what we are.' 'For that is what we are': having not initially acknowledged the existence of an 'indigenous' category, the Zapatistas came to define themselves almost exclusively in terms of this category. ${ }^{7}$ Since then, the Zapatistas' self-representation has not experienced substantial changes.

\section{The period 1996-2000}

By the middle of 1996, the negotiations between the Mexican government and the EZLN were essentially deadlocked. With accusations on both sides of intransigence and arguments over how exactly to proceed, dialogue began to break down and exhaustion set in amongst those charged with mediating the process. Despite the rhetoric favoring peace, it is probable 
that neither side really wanted a solution to the armed conflict. Instead, the real political strategy concentrated on trying to wear down the enemy and question its credibility before public opinion. The government tried to frustrate and reduce support for the Zapatistas through military pressure, increasing politically motivated aid projects, division and cooption, whilst at the same time attempting to underplay the social fragmentation occurring in the region. The Zapatistas, on the other hand, tried to hinder and obstruct national politics and delegitimize the government as much as possible (with absurd exaggerations such as claiming that a genocidal war was being waged with the aim of exterminating indigenous people in Chiapas). Basically, the EZLN was trying to win time, perhaps thinking about the elections to be held in 2000, or perhaps foreseeing a new scenario in which the crisis would become so severe that the EZLN would again be able to take on its revolutionary role on the national stage. Meanwhile, the direct victims of the situation, which was neither war nor peace, were the indigenous people whose living standards further deteriorated, whilst violence spread and intercommunal disputes - often encouraged by the Chiapas state government - produced incessant murders and thousands of internal refugees.

During the period between 1996 and 2000, both the activity and notoriety of the EZLN decreased and became accepted as 'normal', in the sense that the EZLN became yet another actor in the Mexican political scene. Although it did remain an 'atypical' actor because its legitimacy did not depend on elections but on the fact that it supposedly represented indigenous people in Chiapas and defended indigenous rights in general, rights that the government repeatedly refused to acknowledge. As Mexicans' interest in the Zapatistas lessened, the attempts to court their attention required more and more effort and often seemed to be disproportionate to the results achieved. One such attempt was the creation of a Zapatista political organization at a national level - the Zapatista Front of National Liberation (Frente Zapatista de Liberación Nacional - FZLN) which was defined as "A political force that can organize the citizens" demands and proposals so that who ever commands, does so by obeying. A political force that can organize a solution to collective problems without the intervention of political parties or the government' (EZLN 1997: 79). In theory the Zapatista army was going to integrate itself with this organization, depending on the verdict of a national referendum held throughout the country. However, it ended up being seen as a sort of 'sister' organization, restricted to articulating the EZLN's policies beyond Chiapas.

In contrast, during these years the Zapatistas paid growing attention to its international sympathizers, particularly groups belonging to the 'anti-globalization' movement, holding, for example, in Chiapas and other countries, consecutive encounters 'for humanity and against neoliberalism'. In this case, in contrast to the parallel popular-nationalist language, subcomandante Marcos was able to find in the language of the anti-globalization movement a discourse somewhat akin to his own political development. It was also expressed in conveniently vague and euphemistic terms, where 'civil society' came to stand for 'the people' or 'the working class' and 'neoliberalism' for 'capitalism', etc. The anti-globalization movement, as had happened before in the Mexican context with ideas concerning the nation, was thus able to recognize its own discourse reflected in the mirror of an 'indigenous' voice, consequently conceding it greater value and meaning. But for the most part, this international support was inconstant and often immature, even more so than Mexican support for the EZLN, and it became clear that, except for a few exceptions, the Zapatistas could not really count on it.

However, all this should not mean that we lose sight of the fundamentally tactical nature of Zapatista policy after the 1994 uprising. The defense of indigenous rights on a national level and the stance taken against globalization and neoliberalism on an international level 
were not so much ends in themselves but the means that justified an intervention in Mexican politics, or, to put it more plainly, means that justified a broad mobilization against the Mexican state. It is revealing that subcomandante Marcos' criticisms of neoliberalism particularly stressed its capacity to erode national sovereignty. With regards to the relationship between the indigenous cause and national politics, any one of the communiqués clarifies this: 'The struggle of indigenous Mexicans has its particularities and its own demands, but these will only be resolved if broader national problems, which affect the great majority of Mexicans, find a basis for their resolution; these are the lack of democracy, liberty and justice' (EZLN 1995b: 359).

Therefore, if the main goal of the EZLN's strategy was not the indigenous population but a struggle against the state, we might begin to doubt whether we are really dealing with identity politics here or not. Furthermore, this is precisely the nature of identity politics: 'to claim power on the basis of labels ... [therefore] whilst it is true that the narratives of identity politics depend on memory and tradition, it is also true that they are "reinvented" in order to take advantage of the failure or erosion of other sources of political legitimacy: the discrediting of socialism or the rhetoric of the first generation of post-colonial leaders. Such retrospective projects emerge from the void left by the absence of future projects' (Kaldor 2001: 22).

These 'tactical detours', however, ended up being double-edged swords and during this period they ran the risk of sparking unsympathetic reactions amongst the Mexican public. The wariness and nuances in Marcos' declarations reveal the fear, for example, that the question of indigenous autonomy might be interpreted as an attempt at secession, an accusation made by some of his critics. The Zapatistas insisted on revealing themselves as the most patriotic amongst Mexicans, as if they wished to 'remind' people of something that at the beginning of the uprising seemed obvious and had now faded. As Marcos wrote in a letter of thanks to international supporters:

We, our blood once in the voice of our greatest grandfathers, were walking this land when it did yet not have that name [i.e. Mexico]. But later, in this never ending struggle, between being and not being, between staying and leaving, between yesterday and tomorrow, it arrived in the thoughts of our people, now with blood from two races, that this piece of land and water and sky and dream that we had because it was a gift from our ancestors was called Mexico. Thus we became more numerous and then history behaved in a proper fashion, because we were all born with a name of our own. And we called ourselves Mexicans and they called us Mexicans. Later, History continued with its jolts and pains. We were born amongst blood and gunpowder, and amongst blood and gunpowder we were raised. Every now and then, the powerful came from other lands wanting to steal our tomorrow from us. So it was written in the warrior song that unites us [i.e. the Mexican national anthem] 'But if a foreign enemy dared to profane your soil with his feet, think, oh dear Mother Land, that heaven gave you a soldier in every son'. That is why we fought yesterday. With different flags and languages the stranger came to conquer us. He came and he went. We are still Mexicans because we have never felt at ease with any other name, nor would we walk under a flag different to that which has an eagle devouring a snake on white background, with green and red on the two sides. We, the first inhabitants of these lands, became gradually forgotten and left in a corner ... (Subcomandante Marcos 1995b)

An 'Indian' text, in theory written for foreign sympathizers, but largely devoted to emphasizing the Mexicanness of the (Zapatista) Indians. In this insistence we find something 
more than the conventional disclaimer, very common in the Indian politics of other Latin American countries, which maintains that indigenous autonomy does not imply the 'balkanization' of the nation. Rather, it is the opposite in this case, the other side of that ambivalent coin occupied by indigenous people in their respective nations; that is, the invoking of the fact that indigenous people, by being indigenous, are essential Mexicans and, consequently, have the right to mediate in the country in a way that perhaps other groups cannot presume to do so.

With regards to the support given to the EZLN by various international groups, this also presented a delicate issue - even if the question of the financial assistance provided by foreign non-governmental organizations is left to one side. On the one hand, it represented a potent element of international pressure on the Mexican government, which from the period of Salinas de Gortari and particularly during the presidency of Ernesto Zedillo revealed itself to be very sensitive to international opinion. But this direct international support for the Zapatistas could equally be interpreted and presented as a threat to national sovereignty. The widely broadcast television images of international volunteers (Spaniards, if my memory serves me) taking a leading role in Zapatista communities in Chiapas and receiving journalists certainly damaged the EZLN's national image more than the government's own propaganda. This underlined the essentially tactical character of the association between the Zapatistas and the anti-globalization movement: whilst the latter had worldwide objectives, the EZLN's interest was primarily within the Mexican arena. In sum, the 'indigenous' profile as much as the 'anti-globalization' one, provided propaganda advantages, but also risks, particularly if it was seen that an alliance was being forged between foreigners and indigenous people. Nobody that I know of remembered the attempts to forge alliances between Mayas and foreigners during the caste war in Yucatan, ${ }^{8}$ but undoubtedly the ghost of an Indian betrayal of the nation for the benefit of a foreign power - so extensive in the rest of Latin America - remained below the surface for some time.

\section{The electoral defeat of the PRI}

In July 2000, Vicente Fox won the Mexican presidential elections and the PRI lost. Some weeks later, on August 20th, Pablo Salazar, supported by the PRD, the PAN and other minor parties, won the Chiapas governorship elections and the PRI again lost. Evidently, the Zapatista army had mobilized against the state and not just against the PRI, but to the extent that the two were partly identified with each other and especially because of the struggle against 'one-partyism' and the government's rejection of the San Andrés Accords, which had turned into a further justification for the EZLN, the PRI's electoral defeat placed the Zapatistas in an awkward position. The federal and state governments now had all the legitimacy bestowed by representative democracy, supported by the participation of Chiapas' Indians. A pro-Zapatista Mexican publication perfectly summed up the new situation in its headline 'Electoral siege of the EZLN'. As, for obvious reasons, subcomandante Marcos was not a supporter of democratic elections, although his declarations on this issue were characteristically vague ('those rule in a democracy, should do so through obeying'), the EZLN's policy in Chiapas had demonstrated their open rejection of elections and political parties: in the 2000 elections, the Zapatistas abstained and the previous elections were boycotted and even ballot boxes were burnt. ${ }^{9}$

But, at the same time, the change of government offered the Zapatistas a valuable opportunity to win over national attention again. In order to resume the peace talks, the EZLN set the condition that the Law on Indigenous Rights and Culture had to be approved, 
a law that represented a version of a text agreed upon during the first panel in San Andrés. Meanwhile, the Zapatistas organized an impressive march to Mexico City of its comandantes and subcomandante which, after touring the south of the country, arrived in the capital's central plaza in March 2001. Finally, the Mexican congress and senate modified the text of the law that President Fox had presented, which would have entailed the modification of various constitutional articles, particularly aspects to do with 'indigenous autonomy'. The march to Mexico City, like a flare that burns brightly and then goes out, was undoubtedly a great propaganda success, but it did not have much political impact. It appeared that the Zapatistas did not know what to do with their success, as if they did not know how to turn their media presence into political advantage. Their capacity to improvise new strategies according to immediate political circumstances, which had given them many advantages in the past, seemed to be exhausted. They stubbornly held onto the approval, without changes, of the Indigenous Rights Law and in the end the only response that they gave was to break contacts with the government and a long silence that they have kept up until the present (January 2003).

In any case, the PRI's electoral defeat underlined even more the fact that the public identified the Zapatistas as defenders of the Indian cause - irrespective of the Zapatistas themselves. It became increasingly evident to everyone that the EZLN's pretensions to intervene in national politics were no longer justified. And although some still formally maintained the idea that after the 'indigenous law', the government should negotiate the remaining panels of the San Andrés Accords ('democracy and justice', 'welfare and development' and 'women's rights'), in fact nobody really took this possibility seriously. The indigenous issue was becoming disconnected from the broader questions of state reform. Consequently, if the Zapatistas were in charge of 'indigenous issues', this no longer gave them access to the national arena.

What definitely seems to have occurred over the last few years is a change in the way the indigenous question is perceived in Mexico. The public interest 'in the Indians' suffered a drastic decline and, above all, this sector of the population ceased to be a decisive factor for understanding the country or for embarking on its transformation. If, as we have seen, the indigenous 'problem' emerges in public discourse at particular moments when the country suffers an identity crisis, its disappearance is a symptom of the fact that ideas regarding this identity are in a process of reorganization. (It is also true that during this period, international interest in indigenous peoples, whether they be Zapatistas in Chiapas, ecologists in the Amazon or others, lost part of its value as a symbol of 'resistance' against capitalism.) The vague but insidious sensation began to spread that perhaps the promotion of an Indianist politics had gone too far, and that it had not considered sufficiently its inherent risks and drawbacks; but, above all, that it had ignored the problem of poverty in general, that is, poverty without ethnic affiliations. Even those academics that had promoted the idea of indigenous autonomy with great insistence began to change their minds and, more or less publicly, pointed to economic inequality as one of the country's main problems. It is also probable that indigenous identity politics, which had proved themselves so effective against PRI governments, no longer appeared to be a useful way of mobilizing opposition against President Fox's government. After all, and despite the rhetoric of the left, liberal politics seemed to feel comfortable with Indianist positions to the extent that the latter did not present demands for radical economic redistribution and social justice. To conclude, the separation between 'Indians' and 'the poor' that occurred between 1994 and 1996 now returned to haunt them. Almost without realizing, the EZLN leadership found itself alone in defending something - 'indigenous rights' - that it did not really have an interest in defending and with which it never truly politically associated itself in any case. 


\section{A provisional conclusion}

The arrival on the scene of the Zapatistas as an ethnic and identity-based movement implied both its strengths and weaknesses. It was the association between 'indigenous' people and the EZLN that undoubtedly catalyzed the extraordinary resonance and sympathy towards the Zapatistas and their subcomandante in Mexico and abroad. But it also represents its limitations. Despite rhetorical declarations to the contrary, an army that was born to take power in Mexico and effect a socialist revolution had to drastically reduce its aspirations on adopting a strategy of indigenous identity politics. Whilst the PRI remained in power, the EZLN's Indianism allowed it, to a certain degree, to sustain itself as a force that delegitimized the state, but the democratic transition made its aspirations untenable and reduced its possible field of action to a local level and to only one sector of the population.

This strategic development, which in reality had nothing peculiar about it except perhaps for the speed with which the changes occurred, has ended up as a dilemma for the Zapatistas: they either remain as a defense group for 'indigenous rights and culture', or they abandon this position and return to being a leftist organization - revolutionary or with universal ambitions. Both possibilities present advantages and difficulties, but each one responds to a distinct logic and necessitates different things as well; like water and oil, they don't easily mix together. The first option, to the extent that Indians do not again acquire prominence in the Mexican national imaginary, restricts the EZLN's political aspirations in disadvantageous ways. But becoming a leftist group again, which would seem the most logical option given present circumstances, presents its own problems. The pretension to represent the Indians, which is increasingly difficult to sustain, does not currently provide the necessary legitimacy to intervene publicly; this must now be won through elections (and it cannot be ignored that throughout these years the EZLN has remained an armed organization). But abandoning its symbols of indigenous identity, the ending of the ventriloquism effect, apart from not being easy if it is done in too obvious a way, would reduce the EZLN to the status of just another group of the many that abound in the Mexican political scene.

I believe that there exist certain indications that represent an attempt to abandon the ethnic label. For example, the most pro-Zapatista sectors in Mexico now tend to speak of 'popular resistance' and call upon 'the rural and urban population to pool their organizational efforts against governmental neoliberal violence'. It is not exactly a Marxist vocabulary, but neither is it particularly 'Indian'. The silence kept by subcomandante Marcos appears to have been almost eloquent. But it is more notable the fact that at the end of 2002 he broke his silence of almost a year and a half not to talk about the Indigenous Law or some similar issue, but to give his opinion about the internal politics of Spain (a different country, another continent), needlessly insulting certain Spanish authority figures and tacitly supporting the terrorist activity of the organization ETA (later the issue became increasingly confused and, in the height of absurdity, Marcos offered himself as a mediator between the ETA and the Spanish government). Perhaps it was the need for attention again, but on this occasion it had nothing to do with Indians, and, besides, he could not have chosen a worse excuse to launch himself in European politics. In any case, Marcos' various declarations and his exchange of letters with the ETA has had a very limited impact in Spain and the rest of Europe, and revealed the difficulties to be faced if he wishes to change political scene. When he does not speak for the Indians and in favor of the Indians (or about very general principles that the latter implicitly embody) he does not appear to have much public credibility, as happened with his interventions during the student strike at the Mexican National Autonomous University (UNAM). And, as has occurred before with so many leaders, the idyll that existed between Marcos and Mexican and foreign 
intellectuals - with a few exceptions, particularly amongst the latter - appears to have withered.

We are familiar with subcomandante Marcos' talent for remaining on the political scene as a leading player. After all, the history of the EZLN after 1994 is a history of survival in difficult conditions through an impressive ability to adapt, stage and remain sensitive to the feelings of public opinion. But it is probable that it is now stuck. It has no real alternative but to retrace its steps and stop being 'indigenous', although this is no simple matter because identity politics represent a one-way street: once its rhetoric is adopted and, through it, its logic (not the other way around), it becomes extremely difficult to present oneself in public in a different way. It is not easy to practice ventriloquism without Indians and without a mask.

\section{Notes}

1. The commonplace mistakes regarding the social and economic conditions of Chiapas Indians circulated for considerable time and continue to do so. For a critical revision of some of them, see Viqueira (1999). For a history of the sociopolitical changes experienced in the indigenous world in the last 10 years, see Rus (1995). A broad and fairly complete vision concerning the indigenous people of Chiapas can be found in Viqueira and Ruz (1995).

2. Of course there are some exceptions, such as the very valuable testimony (because, amongst other things, it perfectly reflects the indigenous logic in interpreting the conflict) of Pérez Tzu (2000) put together by Jan Rus. With regards to how the character of subcomandante Marcos was interpreted by the Tzeltals of Cancuc, see Pitarch (2001).

3. With regards to this, see Pitarch (1995).

4. I have eliminated here a new paragraph.

5. For a balanced and incisive study of the role of the diocese of San Cristóbal and its bishop in the conflict, see Meyer (2000).

6. For a critical account of the concept and application of 'usos y costumbres' in Indian communities, see Escalante (1998), Bartra (1998) and Viqueira (2001).

7. These types of quotations, however, should not be considered as definitive proof of the EZLN's political positions, as they actually vary considerably (and are often erratic) within short periods of time, depending on the potential public or the circumstances that change from week to week, amongst other factors.

8. The inevitable reference regarding this is the book by Sullivan (1989).

9. Concerning elections and indigenous people in Chiapas, see the book by Viqueira and Sonnleitner (2000).

\section{References}

Bartra, R. (1998) Violencias salvajes: usos, costumbres y sociedad civil. Claves de Razón Práctica, 87, 56-63.

ChiAPas (1994) Chiapas: la palabra de los armados de verdad y fuego I. Entrevistas, cartas y comunicados del EZLN (Barcelona: Ediciones Serbal).

Colectivo Solidaridad Ya (1998) El drama de Chiapas. El País, 22 March, 35

Crocker, J. C. (1983) Being and essence: totemic representation among the Eastern Bororo. In R. Crumrine and M. Halpin (eds) The Power of Symbols: Masks and Masquerade in the Americas (Vancouver: University of British Columbia Press), 154-173.

De La Grange, B. and Rico, M. (1998) Subcomandante Marcos, la genial impostura (Madrid: Aguilar).

Díaz-Polanco, H. (1997) La rebelión zapatista y la autonomía (Mexico City: Siglo XXI).

Escalante, F. (1998) Retórica y poética del usocostumbrismo. Vuelta, 256, 17-21.

EZLN (1994a) Declaración de la Selva Lacandona. In EZLN, Documentos y comunicados (Mexico City: ERA), 33-35. EZLN (1994b) Segunda Declaración de la Selva Lacandona. In EZLN, Documentos y comunicados (Mexico City: ERA), 269-276.

EZLN (1995a) Entrega del baston de mando en el aniversario del EZLN. In EZLN, Documentos y comunicados, vol. 2 (Mexico City: ERA), 139-140.

EZLN (1995b) Mensaje a la II Asamblea Nacional Indígena. In EZLN, Documentos y comunicados, vol. 2 (Mexico City: ERA), 358-359.

EZLN (1997) Cuarta Declaración de la Selva Lacandona. In EZLN, Documentos y comunicados, vol. 3 (Mexico City: ERA), 79-89. 
FLORES, J. (1994) Chiapas: pluralismo cultural y conocimiento indígena. La fornada, 17 January.

García de León, A. (1994) Prólogo. In EZLN, Documentos y comunicados (México City: ERA), 11-29.

KALDOR, M. (2001) Las nuevas guerras. Violencia organizada en la era global (Barcelona: Planeta).

LAmpe, A. (1996) ¿Guerra justa o paz justa? Reflexiones teológicas sobre la lucha armada en Chiapas (Mexico City: Centro Antonio Montesinos-Comunidades Eclesiales de Base-Centro de Estudios Ecuménicos).

LEYva, X. (1995) Catequistas, misioneros y tradiciones en Las Cañadas. In J. P. Viqueira and M. H. Ruz (eds) Chiapas, los rumbos de otra historia (Mexico City: UNAM-CIESAS-CEMCA-UDG), 375-405.

LomNiTz, C. (1999) Ritual, rumor y corrupción en la conformación de los 'sentimientos de la nación'. In C. Lomnitz (ed.) Modernidad Indiana (Mexico City: Planeta), 187-220.

Meyer, J. (2000) Samuel Ruiz en San Cristóbal (Mexico City: Tusquets).

PÉRez, M. and Rojas, R. (1994) Comandante Marcos: el EZLN tiene diez años de preparación. La fornada, 2 January.

PÉRez Tzu, M. (2000) Conversaciones ininterrumpidas: las voces indígenas del mercado de San Cristóbal. In. J. P. Viqueira and W. Sonnleitner (eds) Democracia en tierras indígenas. Las elecciones en Los Altos de Chiapas (1991-1998) (Mexico City: IFE-El Colegio de México-CIESA), 259-267.

Pitarch, P. (1995) Un lugar dificil: estereotipos étnicos y juegos de poder en los Altos de Chiapas. In J. P. Viqueira and M. H. Ruz (eds) Chiapas, los rumbos de otra historia (Mexico City: UNAM-CIESAS-CEMCA-UDG), $237-250$.

Pitarch, P. (2001) El retorno de Juan López. Cuadernos Hispanoamericanos, 608, 97-103.

Ramos, A. R. (1994) The hyperreal Indian. Critique of Anthropology, 14, 62-81.

Redondo, P. (2002) El alzamiento zapatista: una lucha indefinida (Salamanca: Instituto de Estudios de Iberoamérica, Salamanca).

Rus, J. (1995) Local adaptation to global change: the reordering of native society in Highland Chiapas, 1974-1994. European Review of Latin American and Caribbean Studies, 58, 71-89.

Subcomandante Marcos (1995a) Carta a Adolfo Gilly. In EZLN, Documentos y comunicados, vol. 2 (Mexico City: ERA), 104-109.

Subcomandante Marcos (1995b) La flor prometida. El País, 29 March, 4.

Sullivan, P. (1989) Unfinished Conversations: Mayas and Foreigners Between Two Wars (New York: Alfred Knopf).

Viqueira, J. P. (1999) Los peligros del Chiapas imaginario. Letras Libres, 1, 23-31.

VIQUEIRA, J. P. (2001) Los usos y costumbres en contra la autonomía. Letras Libres, 21, 30-34

ViqueIRA, J. P. and Ruz, M. H. (eds) (1995) Chiapas: los rumbos de otra historia (Mexico City: UNAM-CIESASCEMCA-UDG)

Vigueira, J. P. and Sonnleitner, W. (eds) (2000) Democracia en tierras indígenas. Las elecciones en Los Altos de Chiapas (1991-1998) (Mexico City: IFE-El Colegio de México-CIESAS). 